\title{
STRATEGI KOMUNIKASI SATGAS COVID-19 DALAM MENYOSIALISASIKAN PROKES KEPADA LANSIA DI DESA PENATAHAN
}

\author{
Dewa Ayu Ambarawati1, I Made Wirya Darma 2 \\ Ilmu Komunikasi, Universitas Pendidikan Nasional \\ Email: ${ }^{1}$ upik0662@gmail.com,2wiryadarma@undiknas.ac.id
}

\begin{abstract}
Abstrak
Sosialisasi protokol kesehatan semakin digencarkan oleh pemerintah, hal ini dilakukan untuk menekan angka pasien COVID-19. Dengan dilakukannya pembentukan Tim SATGAS COVID-19 di setiap Desa untuk membantu pemerintah dalam memberikan edukasi kepada masyarakat. Di Desa Penatahan Tim SATGAS COVID-19 berfokus kepada para lansia dalam memberikan edukasi mengenai protokol kesehatan, hal ini dilakukan karena para lansia memiliki keterbatasan dalam mengakses media sosial. Sehingga mendapatkan informasi dan pemahaman yang pasti mengenai hal tersebut, perlu adanya edukasi secara langsung kepada lansia. Dengan menerapkan strategi pendekatan persuasif fan edukatif agar tercapainya hubungan timbal balik yang seimbang dari proses sosialisasi protokol kesehatan. Metode pelaksanaan yang diguakan adalah dengan wawancara dan melakukan observasi langsung kelapangan untuk memperoleh data yang valid. Hasil pengabdian ini, kedepannya masyarakat khususnya kalangan lansia menjadikan protokol kesehatan sebagai bagian dari kebiasaan hidup sehat dalam keseharian mereka terutama saat pandemi seperti ini.
\end{abstract}

Kata Kunci: Lansia, Protokol Kesehatan, Strategi Pendekatan Persuasif Dan Edukatif

\begin{abstract}
Socialization of health protocols is being intensified by the government, this is done to reduce the number of COVID-19 patients. With the formation of the COVID-19 SATGAS Team in each Village to assist the government in providing education to the community. In Penatahan Village, the COVID-19 SATGAS Team focuses on the elderly in providing education about health protocols, this is done because the elderly have limitations in accessing social media. So that to get definite information and understanding about this, it is necessary to have direct education to the elderly. By applying a persuasive and educative approach strategy in order to achieve a balanced reciprocal relationship from the health protocol socialization process. The implementation method used is interviews and direct field observations to obtain valid data. As a result of this service, in the future the community, especially the elderly, will make health protocols part of their daily healthy habits, especially during a pandemic like this.
\end{abstract}

Keywords: Elderly, Health Protocol, Persuasive and Educational Approach Strategies 


\section{PENDAHULUAN}

Kabupaten Bangli, menjadi salah satu kabupaten yang masuk kedalam zona merah persebaran COVID - 19. Berdasarkan informasi dari Humas Gugus Tugas Percepatan Penanggulangan ( GTPP ). Pada awalnya Kabupaten Bangli telah menembus angka 1000 kasus masyarakat yang terpapar virus. Teradi penambahan sebanyak 7 kasus baru masyarakat yang terpapar oleh virus, penambahan kasus teradi di kelurahan kawan dan kelurahan cempaga masing - masing 2 orang, serta satu orang asal Desa Bunutin.

Sedangkan sisanya masing - masing satu orang dari Desa Abuan Keamatan Susut, dan Desa Songan Kecamatan Kintamani. (https:// bali.tribunnews.com)

Secara administrasi Kabupaten Bangli, terbagi menjadi 4 wilayah kecamatan dan 68 desa dan 4 kelurahan yaitu : Kecamatan Susut (9 Desa), Kecamatan Bangli (4 Kelurahan dan 5 Desa), Kecamatan Tembuku (6 Desa) dan Kecamatan Kintamani (48 Desa). Luas wilayah Kabupaten Bangli adalah 52.081 Ha atau 9,24\% dari luas wilayah Provinsi Bali (563.666 Ha). Ibu kota Kabupaten Bangli adalah Kawasan Perkotaan Bangli, meliputi Kelurahan Kubu, Kelurahan Cempaga, Kelurahan Kawan dan Kelurahan Bebalang. (RPI2JM Kab. Bangli 20182020)

Dari empat kecamatan yang ada di Bangli, Kecamatan Susut menjadi salah satu kecamatan yang masuk ke dalam zona merah, hal ini disebakan dengan adanya kasus yang terjadi di Desa Srokadan, kejadian tesebut terjadi karena adanya 13 kasus transmisi lokal,sebanyak 8 orang dinyatakan positif

yang disebabkan dari salah satu warga yang merupakan Pekerja Migrasi Indonesia (PMI) yang menjalankan karantina mandiri dirumah. (https://bali.tribunnews.com)

Hal tersebut menyebabkan sempat adanya Lockdown di Desa tersebut, pemerintah kabupaten Bangli segera memeberi himabuan, untuk membentuk Tim SATGAS COVID-19.

Desa Penatahan merupakan salah satu desa yang memiliki tim SATGAS COVID-19, tim ini dibentuk dalam rangka untuk membantu memberikan edukasi kepada masyarakat mengenai adanya pandemi virus corona. Selain memberikan edukasi tim SATGAS COVI-19 Desa penatahan juga melakukan program penyemprotan disenfektan di rumah - ruamah penduduk setiap hari minggu, dalam kegiatan ini juga disisipkan mengenai bagaimana penerapan protokol kesehatan dimasa pandemi.

Dalam sosialisasi mengenai protokol kesehatan instansi terkait yaitu Dinas Kesehatan Kabupaten Bangli mengunggah poster yang berisikan edukasi mengenai 5 hal penting yang bisa dilakukan untuk mencegah COVID -19 dilaman websitenya https://dikes.banglikab.go.id/.

Sosialisasi yang dilakukan oleh Dinas Kesehatan Kabupaten Bangli hanya bisa diakses oleh remaja dan dewasa yang memahami media sosial dan teknologi. Sedangkan kalangan lansia akan kesulitan untuk mengakses informasi tersebut, dikarenakan keterbatasan penegtahuan untuk melakukan akses media sosial. Beranjak dari hal tersebut perlu adanya peranan tim Satgas COVID-19 dalam memberikan informasi langsung kepada lansia untuk memberikan pemahaman mengenai wabah yang sedang terjadi dan bagaimana cara menyikapi dan mengatasi masalah tersebut.

\section{RUMUSAN MASALAH}

Pada pengabdian masyarakat yag dilakukan di Desa Penatahan, permasalahan yang dihadapi oleh masyarakat di tengah masa pandemi ini adalah kurangnya edukasi yang didapatkan oleh lansia mengenai protokol kesehatan yang diterapkan dimasa pandemi.

\section{METODE PELAKSANAAN}

Metode kegiatan yang digunakan dalam pengabdian masyrakat ini ada dua yaitu wawancara dan observasi.

1. Wawancara secara langsung

Kegiatan ini dilakukan dengan mendatangi langsung narasumber untuk memperoleh informasi secara langsung. Dalam pengabdian masyrakat di Desa Penatahan, penulis melakukan wawnacara dengan narasumber yaitu dari pihak SATGAS. Untuk 
mendapatkan informasi mengenai perkembangan prgram kerja yang telah dilakukan.

2. Observasi

Ovservasi langsung dilakukan untuk melihat, bagaimana perkembangan dari metode yang telah diterapkan dalam upayanya mensosialisasikan protokol kesehatan dimasa pandemi.

\section{HASIL DAN PEMBAHASAN}

Dalam rangka memberikan sosialaisasi kepada para lansia di Desa Penatahan, perlu adanya pendekatan komunikasi dengan menerapkan model jaringan komunikasi.

Dalam bidang kehumasan terdapat model jaringan komunikasi yang dikemukakan oleh Stephen P. Robbins dalam bukunya yang berjudul Organization Behavior: Concepts, Controversies and Aplications (1983), dalam organisasi pada umumnya dikenal dengan lima model jaringan komunikasi, salah satunya adalah model rantai. Jaringan komunikasi model rantai ( chain ), model komunikasi ini menganut hubungan komunikasi garis langsung ( komando ) baik keatas atau kebawah tanpa terjadi suatu penyimpangan. Jika dikaitkan dengan sosialisai maka akan terbentuk skema sebagai berikut:

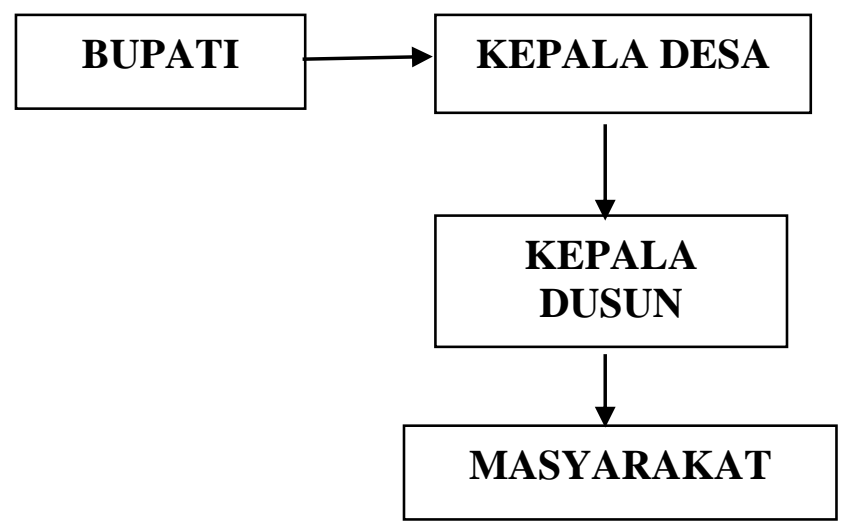

Untuk menerapkan jaringan komunikasi model rantai perlu dimbangi dengan adanya strategi komunikasi, dalam bidang kehumasan memiliki empat strategi pendekatan yang bisa dilakukan dalam rangka memberikan sosialisasi kepada masyarakat, khususnya para lansia, yaitu sebagai berikut:
1. Strategi Oprasional : Bentuk strategi ini lebih berfokus kepada sistematika kegiatan yang bersifat lebih kepada hal - hali teknis, seperti waktu pelaksanaan. Tim SATGAS COVID-19 dalam rangka melaksanakan kegiatan sosialisasi mengambil jadwal di hari minggu, dengan mempertimbangkan bahwa anggota dari tim yang dominan memiliki kegiatan pada saat hari kerja.

2. Strategi Pendekatan Persuasif dan Edukatif : Strategi ini menciptakan komunikasi dua arah ( timbal balik ) dengan menyebarkan informasi dari organisasi kepada pihak publiknya yang bersifat mendidik dan memberikan penerangan, maupun dengan melakukan pendekatan persuasif, agar terciptanya saling pengertian, menghargai dan pemahaman. Untuk menerapkan strategi ini Tim SATGAS COVID-19 Desa Penatahan melakukan sistem jemput bola artinya mengunjungi secara lansung audiensnya, sembari melakukan kegiatan penyemprotan disenfektan, Tim SATGAS juga membelikan sosialisasi kepada lansia mengenai protokol kesehatan yang diterapkan seperti, pemakaian masker, tata cara wajib mencuci tangan saat masuk ke rumah dan pemberlakuan jaga jarak. para Dengan hal ini para lansia di Desa Penatahan mendapatkan edukasi secara merata.

3. Strategi Pendekatan Kerja Sama : Berupaya membina hubungan yang harmonis antara organisasi dengan berbagai kalangan, baik kedalam (internal relations ) maupun hubungan ke luar ( eksternal relations ) untuk meningkatkan kerja sama.

Dalam kegiatan Kuliah Kerja Nyata (KKN) yang dilaksanakan di Desa Penatahan, Kecamatan Susut, Kabupaten Bangli. Program kerja yang dilakukan dalam kegiatan pengadian masyarakat ini adalah melaukan kolaborasi dengan pihak Tim Satgas COVID -19 Desa Penatahan untuk membantu memberikan edukasi kepada para lansia. Strategi komuikasi yang diterapkan saling berkaitan satu dengan yang lainnya, jika satu strategi dihilangkan maka strategi yang lain tidak akan berfungsi dengan baik. 
Maka dari itu hasil dari pengabdian masyarakat ini adalah dari penerapan tiga strategi yang telah dirancang. Strategi komunikasi yang efektif digunakan dalam memberikan sosialisasi kepada lansia adalah strategi pendekatan peprsuasif dan edukatif. Mengapa demikian karena komunikator ( Tim SATGAS ) dengan komunikan ( Lansia ) dapat menciptakan hubungan timbal balik secara langsung, pendekatan persuasif yang dilakukan secara langsung akan mampu memngaruhi pikiran audiens karena komunikator bisa menyesuaikan diri dengan situasi dan kondisi serta memanfaatkan bahasa tubuh yang akan mempermudah pemahaman dari komunikannya. Dari penyususunan strategi ini maka, masyarakat terutama lansia menjadi terbiasa akan penerapan protokol kesehatan secara perlahan dan menjadi mulai terbiasa menggunakan masker dan mencuci tangan saat datang dari berpergian.

\section{KESIMPULAN}

Dalam upayanya melakukan sosialisasi kepada lansia perlu adanya strategi komunikasi yang efektif, guna terjadinya hubungan timabal balik yang sempurna antara komunikator dan komunikan. Pada pengabdian masyrakat di Desa Penatahan, mengenai edukasi kepada lansia tentang protokol kesahatan yang dianjurkan di tengah pandemi. Dengan menerapkan strategi pendekatan persuasif dan edukatif kepada lansia guna menyampaikan informasi mengenai protokol kesehatan. Strategi ini efektif karena antara komunikator dan komunikan dapat bertemu secara langsung sehingga terjadi hubungan timbal balik yang dipatkan dari proses komunikasi yang dilakukan.

\section{DAFTAR PUSTAKA}

https://covid19.banglikab.go.id/

https://sippa.ciptakarya.pu.go.id/sippa_online/ ws_file/dokumen/rpi2jm/DOCRPIJM_153655127 6REV_BAB_II_2017-2021.pdf

https:// bali.tribunnews.com/2021/01/13/tembus -1000-kasus-bangli-masuk-zona-merah-covid-19

Ruslan, Rosady. 2006.Manajemen Public Relations dan Media Komunikasi: Konsepsi dan Aplikasi.Jakarta:Rajawali Pers. 